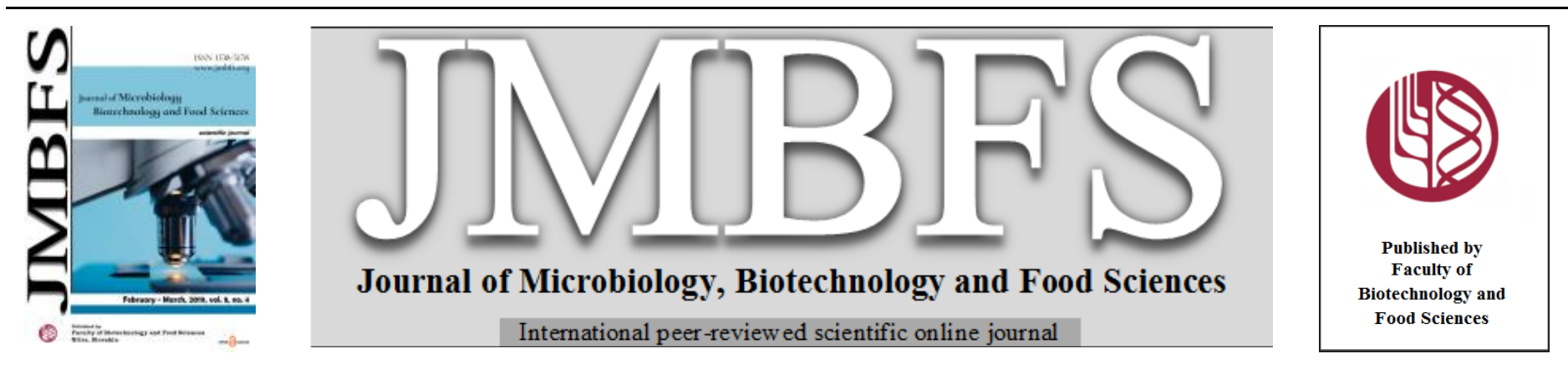

\title{
RESPONSE SURFACE ANALYSIS AND OPTIMIZATION OF OSMOTIC DEHYDRATION OF Musa acuminata SLICES
}

\section{D.Tiroutchelvame $^{1 *}$, J. Prakash Maran ${ }^{2}$, M.M.Pragalyaashree ${ }^{3}$}

\author{
$\operatorname{Address}(e s):$ \\ ${ }^{1,3}$ Department of Food Processing Technology, Karunya Institute of Technology and Sciences, Coimbatore - 641 114, TamilNadu, India. \\ ${ }^{2}$ Department of Food Science and Nutrition, Periyar University, Salem-636 011, TamilNadu, India.
}

*Corresponding author: tirou2011@gmail.com

doi: 10.15414/jmbfs.2019.8.4.1016-1020

ARTICLE INFO

Received 9. 9. 2018

Revised 6. 11. 2018

Accepted 7. 11. 2018

Published 1. 2. 2019

Regular article

open $\odot$ access

\begin{abstract}
The mass transfer characters were quantitatively investigated during osmotic dehydration of Musa acuminata slices using response surface methodology with sugar concentration of $30-50{ }^{\circ}$ Brix, temperature of $30-50^{\circ} \mathrm{C}$, osmotic dehydration time of $30-180$ minutes and sample to solution ratio of 1:5-1:15 g/ml as the independent process variables. Quadratic regression equations were obtained to describe the effects of independent process variables on the weight reduction (WR), solid gain (SG) and water loss (WL). From the results, it was found that, all the independent variables had significant effect on mass transfer characteristics during osmotic dehydration of banana slices. The optimal condition for osmotic dehydration of M.acuminata slices was found to be: osmotic solution concentration of $43^{\circ}$ Brix, sample to solution ratio of $1: 10 \mathrm{~g} / \mathrm{ml}$, osmotic solution temperature of $50^{\circ} \mathrm{C}$ and osmotic dehydration time of 164 minutes respectively.
\end{abstract}

Keywords: M. acuminata slice, Osmotic dehydration, Mass transfer, Optimization

\section{INTRODUCTION}

The fruits and vegetables are inevitable part of the diet of humankind as they are considered to be the prime source of carbohydrates, indigestible minerals, essential amounts of vitamins (especially vitamins A and C) and calories which provide the nutritional values for body building and wellness of the human beings (Salunke et al., 1991). As most of the fruits contain moisture content more than 75 per cent, they are highly prone to the attack of molds and yeasts thereby causing spoilage to this perishable commodity up to 30 per cent of tota production (Janisiewicz et al., 1999). The application of appropriate methods of processing and preservation could definitely reduce the spoilage of fruits and vegetables. Among the various processing and preservation techniques employed to enhance the shelf life of fruits and vegetables, osmotic dehydration (OD) is one of the simple, low cost and energy efficient method based on the removal of natural water content from fruits and vegetables by immersing them in $\mathrm{n}$ hypertonic osmotic solutions prepared with sugars, salts, alcohols and starch solutions (Erle \& Schubert, 2001; Azuara \& Beristain, 2002). The OD process kinetics is influenced by the nature of the osmotic solute and it has a great impact on the nutritional and sensorial properties of the final product (Forni, 1997; Ferrando, 2001)

Musa acuminata is one of the largely consumed fruit around the world and India is the major contributor $(9 \%)$ of the total production. The fruit has high nutritional value, rich in starch and sugars. Apart from these, it also contains good amount of health benefitting anti-oxidants, vitamins A, C and minerals such as phosphorus, potassium, sodium, calcium and magnesium (Borges, 1997). The addition of M.acuminata in our daily diet provides an array of health benefits such as lowering of blood pressure, reduce the development of childhood leukemia, combat the formation of free radicals known to cause cancer, supporting heart health, curing diabetes and so on. Owing to the wide range of beneficial properties of M.acuminata, it is necessary to preserve this fruit from the losses due to perishability and to add value to it in order to make it shelf stable. But, very few research works have been performed by researchers in the osmotic dehydration of M.acuminata using sugar solution as an osmotic agent. Hence, in this present work, response surface methodology (RSM) was used to determine and optimize the effect of process variables (Osmotic sugar concentration, osmotic solution temperature, immersion time and sample to solution ratio) on the mass transfer characters (weight reduction, solid gain and water loss) during osmotic dehydration of M.acuminata slices.

\section{MATERIALS AND METHODS}

\section{Materials}

Fresh M.acuminata (local variety) of uniform size and ripeness were obtained from the local market in Coimbatore, TamilNadu, India. The samples were sorted out visually for homogeneous maturity without having any physical damages, washed in running tap water and surface of the samples were wiped with tissue paper in order to eliminate the surplus water adhering over the surface. After that the peel was removed manually and the pulp was cut into slices of uniform thickness $(2.5 \pm 0.2 \mathrm{~cm}$ diameter and $5 \mathrm{~mm}$ thickness $)$ and stored at $5^{\circ} \mathrm{C}$. The initial moisture content of slices was determined by using hot air oven method (AOAC, 2000) and it was found to be $76.4 \%$ (wb).

\section{Preparation of osmotic solution}

Food grade sugar (99.5\% purity) was purchased from a super market located at Coimbatore, TamilNadu, India. Osmotic solutions of sugar at different concentrations $\left(30,40\right.$ and $50^{\circ}$ Brix) were prepared by dissolving the required quantity of sugar in distilled water and the prepared solution was kept at refrigerated condition prior to experiments. The sugar concentration was measured with a portable refractometer.

\section{Osmotic Dehydration Experiment}

Osmotic dehydration experiments were carried out as per the design of experiments with four different independent variables (sugar concentration, osmotic solution temperature, immersion time and sample to solution ratio) Known weight of M.acuminata slices were immersed in the Erlenmeyer flasks containing required quantity of osmotic solution and kept at temperature controlled chamber in order to maintain the different temperatures $\left(30-50^{\circ} \mathrm{C}\right)$ The Erlenmeyer flasks were covered with a plastic cover during the experiments with the purpose of eliminating the evaporation of osmotic solution. The experiments were carried out at different osmotic solution concentrations (30$50^{\circ}$ Brix), different temperatures $\left(30-50^{\circ} \mathrm{C}\right)$, sample to solution ratio $(1: 5-1: 15$ $\mathrm{g} / \mathrm{ml})$ and immersion time (30-180 min). At specified time interval, the M.acuminata slices were taken out from the hypertonic solution and weighed after removing the solution adhered on the surface of the slices using filter paper (Whatman No.1). Triplicate experiments were carried in the all the experimental condition, mean value was calculated and used to determine the weight reduction (WR), solid gain (SG) and water loss (WL). 


\section{Determination of Osmotic Dehydration Characteristics}

Osmotic dehydration is a two way process where both the water loss and solid gain are acquired simultaneously from the sample as well as from the solution. The reduction in weight is attributed by the loss of water from the slices and increase in the weight of the slices due to solute gain from the solution. The solid gain is the net uptake of solids during osmotic dehydration by the slices on initial weight basis. The water loss (WL) is defined as the net weight loss of the fruit on initial weight basis. The assessment of mass transfer properties (weight reduction (WR), solid gain (SG) and water loss (WL)) between the osmotic solution and samples during this process were estimated by the formula described elsewhere (Tiroutchelvame et al., 2015).

\section{Experimental design and statistical analysis}

Response surface methodology (RSM) is one of the experiential statistical modeling methods employed to obtain experimental data from the appropriately planned experiments to resolve the multivariate equations concurrently. A Box Behnken Design (BBD) with three level four factors was used to plan the experiments and it is exhibited in Table 1. The process parameters opted for the optimization were, osmotic solution concentration $\left(\mathrm{X}_{1}\right)$, sample to solution ratio $\left(\mathrm{X}_{2}\right)$, osmotic temperature $\left(\mathrm{X}_{3}\right)$ and osmotic dehydration time $\left(\mathrm{X}_{4}\right)$. The BBD design comprises of 29 experiments and with three central points. Each process variable was regulated or coded at three levels $(+1,0$ and -1$)$ and coding of the variables was done according to formula described by PrakashMaran et al. (2012). The experimental data was fitted to a second order polynomial equation in order to recognize the appropriate model terms. The general form of the quadratic model can be described elsewhere (PrakashMaran et al., 2013). Multiple regression analysis method was employed on the experimental data in order to evaluate the significance of regression coefficients of process variables. Analysis of variance (ANOVA) tables were generated from the experimental data using Design Expert Statistical Software package 8.0.7.1 (Stat Ease Inc. Minneapolis, USA)

\section{Microstructure analysis}

The fresh and osmotically treated (optimal condition) M.acuminata slices were examined using scanning electron microscopy (SEM) in order to study the influence of osmotic dehydration process on the microstructure of the M.acuminata samples. The microstructure of the samples was viewed under a Jeol scanning electron microscope (JSM-6390) and the images were recorded.

\section{RESULTS AND DISCUSSION}

\section{Model fitting and statistical analysis}

A total number of 29 experiments were performed with different combinations of process variables in order to investigate and optimize the influence of independent variables (osmotic solution concentration, sample to solution ratio, osmotic temperature and osmotic time) on the responses (WR, SG and WL) and the results are shown in Table 1.

\begin{tabular}{|c|c|c|c|c|c|c|c|}
\hline Run No & $\begin{array}{l}\text { Concentration } \\
\left({ }^{\circ} \text { Brix) }\right.\end{array}$ & $\begin{array}{ll}\text { SS } \\
(\mathrm{g} / \mathrm{ml})\end{array}$ & Temperature $\left({ }^{\circ} \mathrm{C}\right)$ & Time (min) & WR $(\%)$ & $(\%)$ & WL $(\%)$ \\
\hline 1 & 40 & $1: 15$ & 40 & 180 & 21.92 & 10.71 & 26.57 \\
\hline 2 & 40 & $1: 5$ & 50 & 105 & 26.05 & 14.86 & 34.85 \\
\hline 3 & 50 & $1: 10$ & 50 & 105 & 35.11 & 20.91 & 49.96 \\
\hline 4 & 40 & $1: 5$ & 40 & 180 & 25.32 & 14.27 & 33.53 \\
\hline 5 & 50 & $1: 10$ & 40 & 180 & 30.16 & 20.71 & 44.81 \\
\hline 6 & 40 & $1: 5$ & 40 & 30 & 23.56 & 13.63 & 31.13 \\
\hline 7 & 40 & $1: 10$ & 30 & 30 & 24.85 & 14.11 & 32.9 \\
\hline 8 & 30 & $1: 10$ & 30 & 105 & 16.64 & 6.29 & 16.87 \\
\hline 9 & 40 & $1: 10$ & 40 & 105 & 36.29 & 26.1 & 53.33 \\
\hline 10 & 30 & $1: 10$ & 40 & 30 & 22.56 & 11.36 & 27.86 \\
\hline 11 & 40 & $1: 10$ & 50 & 30 & 28.45 & 18.26 & 40.65 \\
\hline 12 & 40 & $1: 10$ & 30 & 180 & 21.86 & 10.71 & 26.51 \\
\hline 13 & 40 & $1: 10$ & 40 & 105 & 37.29 & 26.14 & 57.37 \\
\hline 14 & 50 & $1: 5$ & 40 & 105 & 30.51 & 19.35 & 43.8 \\
\hline 15 & 40 & $1: 10$ & 40 & 105 & 37.29 & 19.11 & 47.15 \\
\hline 16 & 40 & $1: 10$ & 40 & 105 & 37.29 & 26.1 & 53.41 \\
\hline 17 & 50 & $1: 15$ & 40 & 105 & 24.26 & 13.06 & 31.26 \\
\hline 18 & 50 & $1: 10$ & 40 & 30 & 30.94 & 19.75 & 44.63 \\
\hline 19 & 40 & $1: 10$ & 50 & 180 & 31.68 & 0.53 & 26.15 \\
\hline 20 & 30 & $1: 5$ & 40 & 105 & 20.91 & 9.75 & 24.6 \\
\hline 21 & 40 & $1: 5$ & 30 & 105 & 24.95 & 13.76 & 32.65 \\
\hline 22 & 30 & $1: 15$ & 40 & 105 & 20.33 & 9.18 & 23.45 \\
\hline 23 & 30 & $1: 10$ & 40 & 180 & 22.55 & 11.35 & 27.84 \\
\hline 24 & 50 & $1: 10$ & 30 & 105 & 29.21 & 18.06 & 41.21 \\
\hline 25 & 30 & $1: 10$ & 50 & 105 & 29.44 & 18.24 & 41.62 \\
\hline 26 & 40 & $1: 15$ & 50 & 105 & 29.44 & 18.25 & 41.63 \\
\hline 27 & 40 & $1: 15$ & 30 & 105 & 15.13 & 3.94 & 13.01 \\
\hline 28 & 40 & $1: 10$ & 40 & 105 & 37.29 & 26.1 & 53.41 \\
\hline 29 & 40 & $1: 15$ & 40 & 30 & 26.11 & 14.92 & 34.97 \\
\hline
\end{tabular}

By applying multiple regression analysis on the experimental data, second-order polynomial equations were developed for the responses which can express the relationship between process variables and the responses. The final equations obtained in terms of coded factors are given below.

$$
\begin{aligned}
& W R=37.09+3.98 X_{1}-1.18 X_{2}+3.96 X_{3}-0.25 X_{4}-1.42 X_{1} X_{2}-1.73 X_{1} X_{3}+0.19 X_{1} X_{4} \\
& +3.30 X_{2} X_{3}-1.49 X_{2} X_{4}+1.56 X_{3} X_{4}-4.96 X_{1}^{2}-7.98 X_{2}^{2}-4.94 X_{3}^{2}-5.30 X_{4}^{2} \\
& S G=24.71+3.81 X_{1}-1.30 X_{2}+2.02 X_{3}-1.98 X_{4}-1.43 X_{1} X_{2}-2.27 X_{1} X_{3}+0.24 X_{1} X_{4} \\
& +3.30 X_{2} X_{3}-1.21 X_{2} X_{4}-3.58 X_{3} X_{4}-3.69 X_{1}^{2}-6.48 X_{2}^{2}-6.20 X_{3}^{2}-5.90 X_{4}^{2} \\
& W L=52.93+7.79 X_{1}-2.47 X_{2}+5.98 X_{3}-2.23 X_{4}-2.85 X_{1} X_{2}-4.0 X_{1} X_{3}+0.050 X_{1} X_{4} \\
& +6.60 X_{2} X_{3}-2.70 X_{2} X_{4}-2.03 X_{3} X_{4}-7.25 X_{1}^{2}-13.05 X_{2}^{2}-9.73 X_{3}^{2}-7.79 X_{4}^{2}
\end{aligned}
$$

Pareto analysis of variance (ANOVA) was used to analyze the experimental data and the results are listed in Table 2 . The higher model $F$-value (68.81for WR, 4.35 for SG, 11.86 for WL) and the associated lower $p$-values $(p<0.0001)$ demonstrated the significance of developed models and also indicated that most of the variation in the responses could be explained through the regression equations. The high value of $\mathrm{R}^{2}$ ( 0.9857 for WR, 0.9131 for $\mathrm{SG}, 0.9223$ for WL) and adj- $\mathrm{R}^{2}$ (0.9714 for WR, 0.9262 for SG, 0.9445 for WL) clearly demonstrated that the form of the model chosen to represent the actual relationship between the response and independent variables is well correlated and accurate. High values of coefficient of variance (3.86 for WR, 25.76 for SG, 12.38 for WL) exhibited 
the high degree of precision and good reliability of the conducted experiments. In this study, the adequate precision (signal to noise ratio) was found to be $>29$ for

Table 2 Analysis of variance (ANOVA) for the developed second order polynomial models

\begin{tabular}{lcccccccccc}
\hline \multirow{2}{*}{ Source } & \multirow{2}{*}{ DF } & \multicolumn{3}{c}{ Weight reduction(\%) } & \multicolumn{3}{c}{ Solid gain(\%) } & \multicolumn{3}{c}{ Water loss(\%) } \\
\cline { 2 - 10 } & & CE & SS & $\boldsymbol{p}$-value & CE & SS & $\boldsymbol{p}$-value & CE & SS & $\boldsymbol{p}$-value \\
\hline Model & 14 & 37.09 & 1085.55 & $<0.0001$ & 24.71 & 971.11 & 0.0047 & 52.93 & 3382.64 & $<0.0001$ \\
$\mathrm{X}_{1}$ & 1 & 3.98 & 190.08 & $<0.0001$ & 3.81 & 173.81 & 0.0052 & 7.79 & 727.43 & $<0.0001$ \\
$\mathrm{X}_{2}$ & 1 & -1.18 & 16.59 & 0.0018 & -1.30 & 20.18 & 0.2796 & -2.47 & 73.36 & 0.0785 \\
$\mathrm{X}_{3}$ & 1 & 3.96 & 188.26 & $<0.0001$ & 2.02 & 48.72 & 0.1023 & 5.98 & 428.53 & 0.0004 \\
$\mathrm{X}_{4}$ & 1 & -0.25 & 0.74 & 0.4313 & -1.98 & 47.01 & 0.1080 & -2.23 & 59.54 & 0.1094 \\
$\mathrm{X}_{12}$ & 1 & -1.42 & 8.04 & 0.0183 & -1.43 & 8.18 & 0.4856 & -2.85 & 32.43 & 0.2276 \\
$\mathrm{X}_{13}$ & 1 & -1.73 & 11.90 & 0.0058 & -2.28 & 20.70 & 0.2736 & -4.00 & 64.00 & 0.0980 \\
$\mathrm{X}_{14}$ & 1 & -0.19 & 0.15 & 0.7223 & 0.24 & 0.24 & 0.9051 & 0.05 & 0.01 & 0.9826 \\
$\mathrm{X}_{23}$ & 1 & 3.30 & 43.63 & $<0.0001$ & 3.30 & 43.63 & 0.1203 & 6.61 & 174.50 & 0.0110 \\
$\mathrm{X}_{24}$ & 1 & -1.49 & 8.85 & 0.0141 & -1.21 & 5.88 & 0.5534 & -2.70 & 29.16 & 0.2514 \\
$\mathrm{X}_{34}$ & 1 & 1.56 & 9.67 & 0.0110 & -3.58 & 51.34 & 0.0944 & -2.03 & 16.44 & 0.3841 \\
$\mathrm{X}_{1}{ }^{2}$ & 1 & -4.97 & 159.90 & $<0.0001$ & -3.69 & 88.10 & 0.0339 & -7.25 & 340.70 & 0.0011 \\
$\mathrm{X}_{2}{ }^{2}$ & 1 & -7.98 & 413.19 & $<0.0001$ & -6.48 & 272.09 & 0.0010 & -13.05 & 1105.50 & $<0.0001$ \\
$\mathrm{X}_{3}{ }^{2}$ & 1 & -4.94 & 158.37 & $<0.0001$ & -6.20 & 249.07 & 0.0014 & -9.73 & 614.72 & $<0.0001$ \\
$\mathrm{X}_{4}{ }^{2}$ & 1 & -5.30 & 182.03 & $<0.0001$ & -5.90 & 225.64 & 0.0021 & -9.79 & 622.00 & $<0.0001$ \\
\hline DF= Degree of Freedom; CE=Coefficient estimate; SS=Sum of Squares. & & & & & & & & &
\end{tabular}

\section{Effect of process variables}

During the early stages of osmotic dehydration of M.acuminata slices, the increase in osmotic solution concentration from 30 to $46^{\circ}$ Brix enhanced the mass transfer properties (WR, SG and WL) (Fig.1). This is due to the fact that smaller molecular weights of the solute (sugar) vigorously infiltrate into the plant tissue and enhances the outflow of water from the inner tissue rapidly to the osmotic solution and increased the WR and WL (Spiazzi \& Mascheroni, 1997) Furthermore, the higher concentration of the solution augments the osmotic pressure gradient and the succeeding loss of functionality of plasmatic membrane of the cell which allows the solute to penetrate into the plant tissues and boosted the SG during the early stages of osmotic dehydration (Fig.1). However, the mass transfer properties of M.acuminata slices decreased beyond $46^{\circ}$ Brix level of sugar concentration (Fig.1) which described that the diffusion strength of osmotic solution (sugar solution) in to the plant material and the comparative moisture content on the outside of product were independent on the concentration of the solution and hence reduced the moisture transport phenomenon of the M.acuminata slices (Lenart \& Flink, 1984).
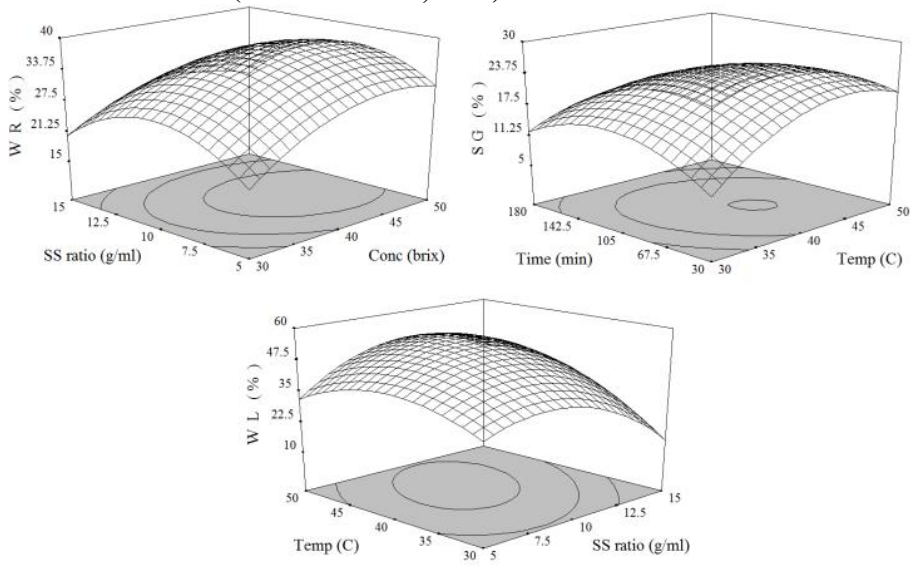

Figure1 Effect of process variables on the mass transfer properties of M.acuminata slices

The significance of sample to solution ratio (SS ratio) on the mass transfer properties of M.acuminata slices was appraised and the outcomes were exhibited in Fig.1. It was observed that the mass transfer properties on the M.acuminata slices during osmotic dehydration showed an increasing trend for the sample to solution ratio from 1:5-1:11 g/ml. This increase in trend may be substantiated by the fact that the higher SS ratio accelerated the driving force of the osmotic solution, enhanced the diffusion of solids from the osmotic solution to plant materials which improved the discharge of water from the plant materials to the surrounding medium (Uddin et al., 2004) and improved the mass transfer properties (Fig.1) of the M.acuminata slices (Tortoe, 2010). However, a decline in the trend was noted beyond the SS ratio of $1: 11 \mathrm{~g} / \mathrm{ml}$ which stated that the osmotic solution became diluted due to the higher amount of water released from the plant tissues during osmotic dehydration which negatively affected the mass transfer properties and confirmed the results obtained by Bongirwar \& Srinivasan (1977).

One of the vital parameters which control the osmotic dehydration properties of the M.acuminata slices is the temperature of the osmotic solution. The effect of osmotic solution temperature on the mass transfer properties of the M.acuminatc slices and the consequences were depicted in Fig.2. Based on the results of the experiments conducted, it was observed that there was an enhancement in water loss from the plant materials and simultaneous uptake of solids (Fig.2) (Ispir $\boldsymbol{\&}$ Toğrul, 2009; Khan, 2012) through swelling and plasticizing of cell membranes (Contreras \& Smyral, 1981 ; Lazerides \& Mavroudis, 1997) while the temperature of the osmotic solution was increased from 30 to $47^{\circ} \mathrm{C}$. However, beyond osmotic solution temperature of $47^{\circ} \mathrm{C}$, the mass transfer properties of M.acuminata slices (Fig.2) decreased which may be due to the predominance of thermal denaturation and affected the cell membrane permeability, decreased the viscosity of osmotic solution and enhanced the altercation of solids into the plant material.

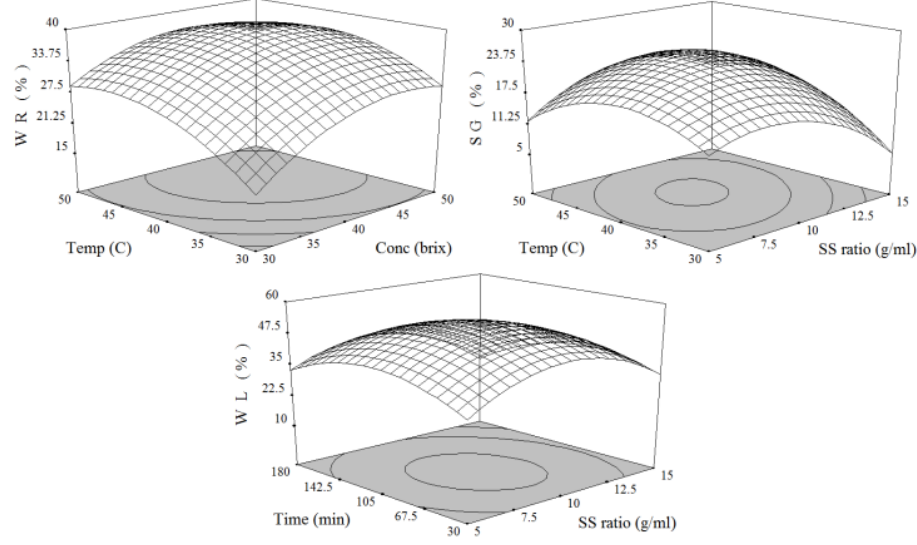

Figure 2 Effect of process variables on the mass transfer properties of M.acuminata slices

Osmotic dehydration experiments were performed at different time levels (30$180 \mathrm{~min}$ ) in order to investigate the effect of immersion time on the mass transfer properties of M.acuminata slices during osmotic dehydration and the consequences were shown in Fig.2. The results revealed that, increase in the immersion time of the sample in the osmotic solution upto 140 minutes caused an improvement in the mass transfer parameters of the samples (Fig.2). This enlightened the fact that the transport phenomena become very rapid during the early stages of dehydration and aided to the progression of mass transfer of solutes due to the feasible membrane enlargement or plasticizing, which forced to enhance the cell membrane permeability to the sugar molecules to infuse into the plant material (Lazerides \& Mavroudis, 1997) and advanced the loss of water from the plant tissues (Lazarides et al., 1995 ; Ertekin \& Çakaloz, 1996 ; Shi \& Maguer, 2002). It was also visualized that after an osmotic dehydration time of 140 minutes, equilibrium level was attained between the sample and the osmotic solution which brought a negative trend in mass transfer rate and decreased the mass transfer properties of the slices (Ertekin \& Çakaloz, 1995). 


\section{Optimization and validation of dehydration parameter}

In this study, desired function methodology was used to identify the optimal osmotic dehydration condition. By using this method and from the results of the osmotic dehydration experiments, the optimized conditions obtained were osmotic solution concentration of $42.36^{\circ} \mathrm{Brix}$, sample to solution ratio of $1: 10.17$ $\mathrm{g} / \mathrm{ml}$, osmotic solution temperature of $50^{\circ} \mathrm{C}$ and osmotic dehydration time of 164.21 minutes and the corresponding values of mass transfer properties were WR $34.08 \%$, SG $12.68 \%$ and WL $40.25 \%$. However, considering the operability in real manufacture, the most favorable condition can be customized as follows: osmotic solution concentration of $43 \%$, sample to solution ratio of $1: 10 \mathrm{~g} / \mathrm{ml}$, osmotic solution temperature of $50^{\circ} \mathrm{C}$ and osmotic dehydration time of 164 minutes. To compare the predicted results with experimental value, triplicate experiments were carried out at the modified optimum condition and the experimental yield (WR of $34.26 \pm 0.48 \%$, SG of $12.63 \pm 0.34 \%$ and WL of $40.419 \pm 0.19 \%$ ) matched well with predicted values.

\section{Microstructural analysis at optimal condition}

Micrographs of osmotically treated and untreated samples are depicted in Fig. 3. The Fig. 3a illustrates that, cytoplasmic membrane and cell walls appeared as the bright regions. The appearance of cells in a tattered and uneven in shape exhibits the existence of several blank regions (Fig.3a). The Fig.3b confirms that, the cells materialized with decrease in size and unclear. It could be possibly due to the solubilization of carbohydrates, loss of water and the salt concentration on the exterior of the plant materials during the process (Raoult-Wack et al., 2007; Torreggiani \& Bertolo, 2001; Garcia et al., 2010). In addition, loss of water might have stimulated the plasmolysis of cells and the stability to the tissues by solute gain (Nunes et al., 2008).
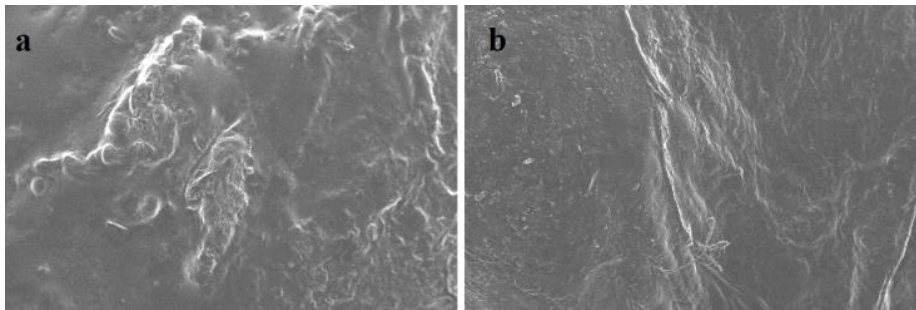

Figure 3 SEM micrograph of raw and osmotically dehydrated M.acuminata slices

\section{CONCLUSION}

Four factors, three levels Box-Behnken experimental design was effectively utilized in this study to evaluate and identify the optimal osmotic dehydration condition in order to prepare osmotically dehydrated M.acuminata slices using sugar solution as an osmotic agent. Three second order polynomial models were framed for the responses (WR, SG and WL) from the observed data. The results exhibited that, all the independent variables have considerable influence on the osmotic dehydration process of M.acuminata slices. The optimum condition was identified by desired function methodology and validated the optimal condition experimentally.

\section{REFERENCES}

ALAKALI, J.S., ARIAHU, C.C., \& NOPA, N.N. (2006). Kinetics of osmotic dehydration of mango. Journal of Food Processing and Preservation, 30, $597-$ 607. https://doi.org/10.1111/j.1745-4549.2006.00080.x

AOAC. (2000). Association of Official Analytical Chemists. Official Methods of Analysis. 17th ed.

AZURA, E., \& BERISTAI, C.I. (2002). Osmotic dehydration of apples by immersion in concentrated sucrose / matlodextrin solution. Journal of Food Processing and Preservation, 26, 295-306.

BONGIRWAR, D. R., \& SRINIVASAN, A. (1977). Studies on osmotic dehydration of banana. Journal of Food Science and Technology, 14, 104-112. BORGES, S.V., \& MENEGALLI, F. C. (1994). Influência da desidratação osmotic sobre a cinética da secagem de manga. Pesquisa Agropecuária Brasileira, 29, 637-642,

CONTRERAS, J. E., \& SMYRAL, T. G. (1981). An evaluation of osmotic concentration of apple rings using corn syrup solid solution. Canadian Institute of Food Science and Technology Journal, 14, 310-314.

ERLE, U., \& SCHUBERT, H. (2001). Combined osmotic and microwavevacuum dehydration of apples and strawberries. Journal of Food Engineering, 49,193-199.

ERTEKIN, F. K., \& ÇAKALOZ, T. (1995). Osmotic dehydration of peas: I. Influence of osmosis on drying behavior and product quality. Journal of Food Processing and Preservation, 20, 105- 119. https://doi.org/10.1111/i.17454549.1996.tb00848.x
ERTEKIN, F. K., \& ÇAKALOZ, T. (1996). Osmotic dehydration of peas: II. Influence of process variables on mass transfer. Journal of Food Processing and Preservation, 20, 87-104. https://doi.org/10.1111/j.1745-4549.1996.tb00849.x FERRANDO, M., \& SPIESS, W.E.L. (2001). Cellular response of plant tissue during the osmotic treatment with sucrose, maltose and trehalose solutions. Journal of Food Engineering, 49, 115-127. DOI: 10.1016/S02608774(00)00218-1

FORNI, E., SORMANI, A., SCALISE, S., \& TORREGIANI, D. (1997). The influence of sugar composition on the color stability of osmodehydrofrozen intermediate moisture apricots. Food Research International, 31, 87-94. DOI 10.1016/S0963-9969(97)00038-0

GIRALDO, G., TALENS, P., FITO P., \& CHIRALT, A. (2003). Influence of sucrose solution concentration on kinetics and yield during osmotic dehydration of mango. Journal of Food Engineering, 58, 33-43. DOI: 10.1016/S02608774(02)00331-X

ISPIR, A., \& TOĞRUL, Đ. T. (2009). Osmotic dehydration of apricot: Kinetics and the effect of process parameters. Chemical Engineering Research and Design, 87, 166-180.

JANISIEWICZ, W.J., CONWAY, W.S., \& LEVERENTZ., B. (1999). Biological control of postharvest decays of apple can prevent growth of Escherichia coli O157:H7 in apple wounds. Journal of Food Protection, 62, 1372-1375 https://doi.org/10.4315/0362-028X-62.12.1372

KHAN, M. R. (2012). Osmotic dehydration technique for fruit preservation - A review. Pakistan Journal of Food Science, 22, 71-85.

LAZARIDES, H. N., KATSANIDIS, E., \& NICKOLAIDIS, A. (1995). Mass transfer kinetics during osmotic pre-concentration aiming at minimal solid uptake. Journal of Food Engineering, 25, 151-166. DOI: 10.1016/02608774(94)00006-U

LAZERIDES, H. N., GEKAS, V., \& MAVROUDIS, N. (1997). Apparent mass diffusivities in fruit and vegetable tissues undergoing osmotic processing Journal of Food Engineering, 31, 315-324. https://doi.org/10.1016/S0260 8774(96)00084-2

LENART, A., \& FLINK, J. M. (1984). Osmotic concentration of potato. II. Spacial distribution of the osmotic effect. International Journal of Food Science and Technology,19, 65-89. https://doi.org/10.1111/j.1365-2621.1984.tb00327.x

LOMBARD, G.E., OLIVEIRA, J.C., FITO P., \& ANDRÉS A. (2008). Osmotic dehydration of pineapple as a pre-treatment for further drying. Journal of Food Engineering, 85, 277-284. http://dx.doi:10.1016/j.jfoodeng.2007.07.009 MUJICA-PAZ, H.,. VALDEZ-RAGOSO, A., LOPEZ- MALO, E.,. PALOU, A. \& WELTI-CHANES. J. (2002). Impregnation and osmotic dehydration of some fruits: Effect on the vacuum pressure and syrup concentration. Journal of Food Engineering, 57, 305-314. https://doi.org/10.1016/S0260-8774(02)00344-8

PEREIRA, L.M., RODRIGUES, A.C.C., SARANT_OPOULOS, C.I.G.L. JUNQUEIRA, V.C.A., CUNHA, R.L., \& HUBINGER, M.D. (2004). Influence of modified atmosphere packaging and osmotic dehydration on the quality maintenance of minimally processed guavas. Journal of Food Science, 69, 172 177. https://doi.org/10.1111/j.1365-2621.2004.tb06343.x

PETROTOS, K.B., \& LAZARIDES, H.N. (2001). Osmotic concentration of liquid foods. Journal of Food Engineering, 49, 201-206.

MANIKANDAN,

S.,

THIRUGNANASAMBANDHAM, K., VIGNA NIVETHA, C., \& DINESH, R. (2012). Box-Behnken design based statistical modeling for ultrasound-assisted extraction of corn silk polysaccharide. Carbohydrate Polymers, 92, 604-611. https://doi.org/10.1016/j.carbpol.2012.09.020

PRAKASHMARAN, J., SIVAKUMAR, V., THIRUGNANASAMBANDHAM, K., \& SRIDHAR, R. (2013). Artificial neural network and response surface methodology modeling in mass transfer parameters predictions during osmotic dehydration of Carica papaya L. Alexandria Engineering Journal, 52, 507-16 https://doi.org/10.1016/j.aej.2013.06.007

RAOULT-WACK, A. L., GUILBERT, S., MAGUER, M., \& RIOS, G. (2007) Simultaneous water and solute transport in shrinking media - Part I. Application to dewatering and impregnation soaking process analysis (osmotic dehydration). Drying Technology, 9, 589-612. https://doi.org/10.1080/07373939108916698 RASTOGI, N., RAGHAVARAO, K., NIRANJAN, K., \& KNORR, D. (2002) Recent developments in osmotic dehydration: methods to enhance mass transfer. Trends in Food Science and Technology, 13, 48-59.

SHI, J., \& MAGUER, M. L. (2002). Osmotic dehydration of foods: Mass transfer and modeling aspects. Food Reviews International, 18, 305-335. https://doi.org/10.1081/FRI-120016208

SOUSA, P.H.M., SOUZA NETO, M.A., MAIA, G.A., SOUZA FILHO, M.S.M., \& FIGUEIREDO, R.W. (2003). Desidratação osmótica de frutos. Bulletin of the Brazilian Society, Science and Food Technology, 37, 94-100.

SPIAZZI, E. A., \& MASCHERONI, R. H. (1997). Mass transfer model for osmotic dehydration of fruits and vegetables-I. Development of the simulation model. Journal of Food Engineering, 34, 387-410.

TIROUTCHELVAME, D., SIVAKUMAR, V., \& PRAKASH MARAN, J. (2015). Mass Transfer Kinetics during Osmotic Dehydration of Amla (Emblica officinalis L.) Cubes in Sugar Solution. Chemical Industry \& Chemical Engineering Quarterly, 21 (4), 547-559. DOI 10.2298/CICEQ140712011T 
TORREGGIANI, D., \& BERTOLO, G. (2001). Osmotic pre-treatment in fruit processing: Chemical, physical and structural effects. Journal of Food Engineering, 49, 247-253. https://doi.org/10.1016/S0260-8774(00)00210-7

TORRES, J.D., TALENS, P., \& ESCRICHE, I.A. (2006). Chiralt Influence of process conditions on mechanical properties of osmotically dehydrated mango. Journal of Food Engineering, 74, 240-246. http://dx.doi.org/10.1016/j.jfoodeng.2005.03.017

TORTOE, C. H. (2010). A review of osmo dehydration for food industry. African Journal of Food Science, 4, 303-324.

TORTOE, C., ORCHARD, J., \& BEEZER, A. (2007). Osmotic dehydration kinetics of apple, banana and potato. International Journal of Food Science and Technology, 42, 312-318. https://doi.org/10.1111/j.1365-2621.2006.01225.x

UDDIN, B. M., AINSWORTH, P., \& IBANOGLU, S. (2004). Evaluation of mass exchange during osmotic dehydration of carrots using response surface methodology. Journal of Food Engineering, 65, 473-477. https://doi.org/10.1016/j.jfoodeng.2004.02.007 